Index Numbers of World Market Prices of Foodstuffs and Industrial Raw Materials

\begin{tabular}{|c|c|c|c|c|c|c|c|}
\hline \multirow{2}{*}{ Index and commodity group } & \multicolumn{4}{|c|}{1967} & \multicolumn{3}{|c|}{1968} \\
\hline & March & June & September & December & March & March 29 & April 11 \\
\hline HWWA-Index $1(1952-1956=100)$ & 91.9 & 92.2 & 80.9 & 97.0 & 99.1 & 97.9 & 96.5 \\
\hline 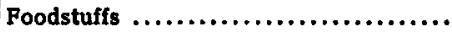 & 84.0 & 86.8 & 84.9 & 90.3 & 90.3 & 90.7 & 90.7 \\
\hline Raw materials other than foodstuffs & 95.7 & 94.8 & 93.8 & 100.2 & 103.4 & 101.3 & 99.3 \\
\hline Futels $\ldots \ldots \ldots \ldots \ldots \ldots \ldots$ & 95.1 & 95.1 & 95,7 & 96.3 & 96.4 & 96.4 & 96.0 \\
\hline Raw materials for consumer goods .. & 92.1 & 91.7 & 89.5 & 93.8 & 93.5 & 94.4 & 92.8 \\
\hline Raw materials for capital goods & 98.8 & 96.6 & 94.7 & 108.2 & 117.1 & 111.0 & 107.0 \\
\hline Reuter's Index (18. 9. 1031) $=100$ & 425.8 & 445.2 & 418.3 & 499.0 & 510.4 & 502.8 & 492.1 \\
\hline Moody's Index (31. 12. $1931=100)$ & 366.2 & 373.8 & 363.9 & 364.3 & 362.3 & 365.9 & 361.8 \\
\hline
\end{tabular}

1 Index compiled by the Hamburg Institute for International Economics. 2 March 14, 1968

risk of an overheating of the economic atmosphere can be excluded for the current year. That finally competition for available manpower will become more keen as soon as industry tries to regain to a certain extent lost workers is by no means critical, since thus compulsion for a rational employment of labour will be growing stronger.

\title{
Raw Material Markets
}

\section{Again Slightly Falling Cotton Prices}

The upward trend in cotton prices since the end of 1966-especially for medium-and long staple typeshas come to a standstill in early February. Since then, quotations at the cotton exchange fell by 2 per cent to $2.81 \mathrm{DM} / \mathrm{kg}$. But the present price level still surpasses by 10 per cent that of one year ago.

During the current season 1967/ 1968, the world cotton market islike in the preceding year- distinctly marked by a drastical reduction of the US cotton production. The restrictive cultivation policy pursued by the Commodity Credit Corporation was so successful that already in the 1966/67 season production with 9.5 million bales lay by one third below the average yields of the previous years. For the season 1967/68, a further production decline by 2.2 million to 7.3 million bales is anticipated, as the once again reduced areas planted were frostbitten considerably. As a consequence, production has fallen below the United States' domestic consumption, which for $1967 / 68$ is estimated at 9.1 million bales. With rather invariable exports of 4.7 million bales annually, a reduction of the stocks amounting to 17 million bales in August 1966 to 7 million bales in August 1968 can be reached.

The production loss in the USA was only partly compensated by increases in the production of other cotton cultivating regions. In 1966/67 world production decreased by 11.1 per cent to 47.3 million bales and, in this season, is supposed to fall by further 1.5 per cent to 46.6 million bales. In contrast to this, world consumption in $1966 / 67$ rose by 1.8 per cent to 51.6 million bales, and for $1967 / 68$ a growth by 1.7 per cent to 52.5 million bales is expected. Within a period of two years only, world stocks will decline by one third to approx. 21 million bales at the beginning of the season 1968/69. Especially stocks of medium-and long staple cotton types will be reduced, so that here shortages will become visible to a growing extent.

Under these circumstances, the slight price decline will not last long. This fall was mainly caused by the restraint of West European processors, which is due to the fact that the cyclical upswing in the cotton textile industry of these countries is advancing but slowly. In case of an acceleration of European demand for cotton, even rising prices would have to be anticipated soon. For the next season 1968/69, however, in the USA a production expansion to 13.5 million bales is intended, which is to comprise above all mediumand long staple types. It will probably hardly be possible to reach such a doubling of production within one year only, but the prospect of noticeably higher yields might set close limits to price increases in the next future.

Erratum:-The heading of column 3 of the table on page 117 in INTERECONOMICS, No. 4, 1968, should read: Volume on March 31, 1967.

\section{INTER E C ONOMICS . Monthly Review of International Trade and Development}

Edited by The Hamburg Instifute for International Economics (Hamburgisches Welt-Wirtschafts-Archiv), Director: Prof. Dr. Heinz-Dietrich Ortlieb, and The German Overseas Institute (Deutsches Obersee-Institut), President: Prof. Dr. Dr. h. c. Andreas Predobl. Editorial Office: Dietrich Kebschull (Chief Editor), Wolfgang Reisener, Hubert Hoping; published by Verlag Weltarchiv GmbH., Address: Eppendorfer Landstrabe 106, 2 Hamburg 20. Advertising Representative: Dr. Hans Klemen. Printed by Otto Sawitzke, 2 Hamburg 70. Annual rate of subscription DM 48,- (US-\$ 12,-). Capyright by Vorlag Woltarchiv GmbH. 